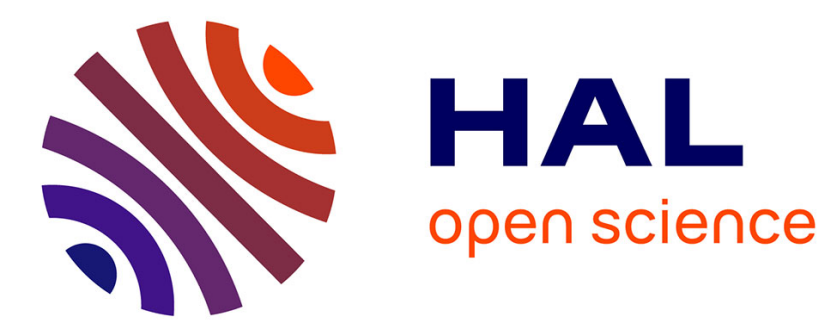

\title{
Recent evolution of non-standard consonantal variants in French broadcast news
}

\author{
Maria Candea, Martine Adda-Decker, Lori Lamel
}

\section{To cite this version:}

Maria Candea, Martine Adda-Decker, Lori Lamel. Recent evolution of non-standard consonantal variants in French broadcast news. pp.412-416, 2013. halshs-00856290

\section{HAL Id: halshs-00856290 \\ https://shs.hal.science/halshs-00856290}

Submitted on 30 Aug 2013

HAL is a multi-disciplinary open access archive for the deposit and dissemination of scientific research documents, whether they are published or not. The documents may come from teaching and research institutions in France or abroad, or from public or private research centers.
L'archive ouverte pluridisciplinaire HAL, est destinée au dépôt et à la diffusion de documents scientifiques de niveau recherche, publiés ou non, émanant des établissements d'enseignement et de recherche français ou étrangers, des laboratoires publics ou privés. 


\title{
Recent evolution of non-standard consonantal variants in French broadcast news
}

\author{
Maria CANDEA ${ }^{1}$, Martine ADDA-DECKER ${ }^{2,3}$, Lori LAMEL ${ }^{3}$ \\ ${ }^{1}$ EA 1483 - CLESTHIA, Sorbonne Nouvelle University, Paris, France \\ ${ }^{2}$ UMR 7018 - LPP, CNRS/Sorbonne Nouvelle University, Paris, France \\ ${ }^{3}$ UPR 3251 - LIMSI, CNRS, Orsay, France \\ mcandea@univ-paris3.fr, madda@univ-paris3.fr, lamel@limsi.fr
}

\begin{abstract}
This paper investigates sociophonetic questions about global tendencies in contemporaneous European spoken French. The authors argue that automatic alignment allowing targeted variants can provide evidence for current hypotheses about possible ongoing sound changes or about destandardization even in formal contexts as broadcast news. This study focused on the evolution over a decade, in radio or TV news, of three 'non- standard' consonantal variants: consonant cluster reduction, affrication/palatalization of dental stops and voiceless fricative epithesis. Measures obtained by this method showed that the first variant remains almost absent in journalists' speech, exactly as affrication of /d/. In contrast, affrication of $/ t /$ is increasing and the fricative epithesis, partially unpredictable, becomes longer. Our findings support the use of automatic alignment as an aid to validate sociolinguistic hypotheses and to develop pattern-driven studies, gathering more variables.
\end{abstract}

Index Terms: sociophonetics, affrication, voiceless fricative epithesis, consonantic cluster reduction

\section{Introduction}

Very large oral corpora with sound/phoneme and sound/word alignment have become available over the last decade but they are generally not used by sociolinguists, mainly because the lack of information about social characteristics of speakers and about contexts. Such corpora are useful for testing recent hypotheses in sociolinguistics about global tendencies in practices of French, e.g. a hypothesis about a considerable degree of levelling [1] through a global tendency both to destandardization (better acceptance of 'non-standard' features even in formal contexts) and devernacularization (lower acceptance of regional or very localized forms even in peer to peer interactions). A "supralocal French" [1] should be observable in large corpora, and a fortiori in a large corpus of broadcast news data which is a compromise between prescriptive and statistical norms (common usage).

This study aims to exploit such available data, originally used at the LIMSI laboratory to train a speech recognition system $[2,3]$, for sociolinguistic purposes. These found data (not produced for research) are interesting because they are sizeable, more than 300 hours, and they are homogeneously structured into series of segments (readings, reports, interviews) characterizing radio or TV broadcast news. Moreover, journalists' pronunciation is considered as very normative, sometimes even as "reference French" [4] since a sample of French students are more demanding with journalists than with teachers in this respect [5].
This study focuses on three non-standard consonantal features in French: consonant cluster reduction (other than cons $+/ 1, \mathrm{R} /$ ), affrication of $/ \mathrm{t}, \mathrm{d} /$ before high vowels and fricative epithesis (i.e. a final voiceless fricative sound added after words normally ending by a vowel). All selected variables were mentioned by Fonagy [6,7] as indicators of the «changing face of French », likely to become ongoing phonetic changes.

\section{Hypotheses about selected variables}

These three non-standard features lead to the proposal of three corresponding hypotheses which are further described below.

\subsection{Consonant cluster reduction}

Reduction of consonantal clusters in spoken French (concerning deletion of $/ 1, \mathrm{R} /$ in final post-consonantal position, or reduction of any cluster of three or four consonants) is an early phenomenon, linked to two factors: speech rate and literacy level. It was already mentioned in the $17^{\text {th }}$ century and it gained salience in the $18^{\text {th }}[8]$ in literature, when peasant or underclass spoken language was stylized.

Post-consonantal deletion of $/ 1, \mathrm{R} /$ in word-final position, e.g. /vivR/ ('to live') pronounced/viv/, is generally considered as quite frequent if the speech rate is high, and thus already included, as variant, in pronunciation dictionaries used by recognition systems in French [9].

Reduction of triple and quadruple consonantal clusters is also a frequent phenomenon in spoken French, graphically conventionalized, attested in modern literature (for example in dialogue verbs 'expliquer (to explain), exprimer (to express), exclamer (to exclaim)' are written 'espliquer, esprimer, esclamer' in [10]) but as well as on the Internet, on blogs, comments, discussions (for example 171k occurrences of "esplique( $r)$ ", 125k occurrences of "esprime $(r)$ " on Google $\circledast$, March 2013). The context/cks/ followed by one or two consonants was selected for focus in this study because it is the most frequent within word pluri-consonantal cluster in spoken French. Following [6,7], the hypothesis of a progression (or at least a significant frequency) in formal contexts will be tested, through the analysis of a broadcast news corpus spanning a decade.

\subsection{Palatalization and affrication of dental stops}

Palatalized dental stops before high semi-vowels have often been mentioned as a peasant or 'working class' indicator in the history of French spoken language. This 'wet' pronunciation actually was velarisation in vernacular Parisian French, from $16^{\text {th }}$ through the early $20^{\text {th }}$ century, since $/ \mathrm{t}, \mathrm{d} /$ were pronounced $/ \mathrm{k}, \mathrm{g} /$ before $/ \mathrm{j} /$ [8], e.g. 'mortier' (mortar) pronounced as 'morquié'. Contemporaneous studies concerning European 
French in various big cities, in particular $[8,11,12]$, speak about palatalization tending to affrication of $/ \mathrm{t}, \mathrm{d} /$ into [t $\mathrm{t}, \mathrm{d} 3]$, not only before high semi-vowels but also before /i,y/, supposed to be frequent in the pronunciation of working class young people of immigrant descent [11]. A similar phenomenon of affrication characterizes Laurentian spoken French in Canada, but in this variety the most frequent forms are closer to $[\mathrm{ts}, \mathrm{dz}]$ and occur in formal and informal contexts, even by educated speakers.

Recent research tends to confirm Fonagy's [6] hypothesis about the increase of strong palatalized tending to affricated pronunciations of $/ t, d /$ in European French. For instance, [13] showed that it occurs in the government representatives' formal speech such as some of ministers in the Fillon government in France (2008). Based on a perceptual experiment, [14] argued that these variants are not salient for young French speakers under age of 25, while [1] considered that this phenomenon could be the single candidate to an ongoing consonantal change in European French.

The competing hypothesis cannot be excluded at the moment. If affrication enters into a stereotyping process, as "urban working class" indicator, its progression will be blocked. Therefore, it is interesting to test whether these variants have been increasing in broadcast news, over the last decade.

\subsection{Fricative epithesis in final position}

Epithesis refers to any parasite letter (or sound) at the end of a word without changing its sense. Unlike the two previous markers, the voiceless fricative unpredictable coda seems to be a quite recent phenomenon, characterizing 'legitimate' speakers in masterful position [15]. This coda mainly occurs after /i,e,y/, sometimes devoiced, in final position of words, generally before the end of a read paragraph or before giving the floor. A typical example is 'merci' pronounced [meRsiç] with the sound [ç] as fricative epithesis.

No mention about this feature could be found earlier than 1989 and only a few studies have been published about it. In 1979 , in a systematical phonetic study of 39 high upper class female speakers, [16] did not mention the parasite consonantal coda, while in 1989 [6] made some sporadic observations about it, attributing this feature mainly to women and to (male or female) journalists, and however focusing his main attention on devoiced vowels rather than on consonantal codas. Based on his own observations, [17] noticed an increase of this feature in media and reported an explicit commenting on it, which showed an intentional production by a young journalist in 2003. Two prior studies with manual acoustic measurements are available: [18] focused on devoiced vowels with fricative coda, concerning 27 examples obtained by elicited reading, and [15] focused on fricative coda, concerning 67 examples selected in 4 hours of radio news on Radio France Internationale station.

This study relied on a methodology based on using stateof-the-art speech recognition technology to locate occurrences of this feature in a large spoken corpus in order to investigate its possible progression in reading style or in authoritative speech.

\section{Corpus and methodology}

Several corpora of broadcast news in French were used for this study, including 86 hours from ESTER benchmark recorded from national radios from 1998 to 2003 [19], 200 hours recorded in 2007 and 32 hours from 2009 to 2010 (national radios and TV), available at LIMSI. These data were transcribed by humans. The automatic alignment made at the phone and word levels were obtained using standard methods for training acoustic models for speech recognition systems, which are explained in [2,3].

All contexts of $/ \mathrm{ks} /$ followed by $/ \mathrm{p}, \mathrm{t}, \mathrm{k} /$ consonants were automatically extracted from 1998-2007 data, embedded in 3 second frames; all corresponding spectrograms were displayed and audio extracts were listened to by the first author.

For the two other markers (affrication of dental stops and fricative epithesis) a similar automatic extraction of all possible contexts generated too many segments to be able to analyze them manually. Therefore, we chose another method by introducing very targeted phonetical principles in our alignment algorithm, which has been initially written for phonemic transcriptions. Some expected consonantal variants were thus given as options in the pronunciation dictionary, as shown below.

Table 1. Variants allowed in alignments. $[\mathrm{HH}=$ audible breath $]$

\begin{tabular}{|c|c|}
\hline Phonemic contexts & Variants as options \\
\hline$/ \mathrm{ti}, \mathrm{tj}, \mathrm{ty}, \mathrm{tu}, \mathrm{te}, \mathrm{to}, \mathrm{ta} /$ & $\begin{array}{l}\text { [ti-t } \mathrm{ti}, \mathrm{tj}-\mathrm{t} \int \mathrm{j}, \mathrm{ty}-\mathrm{t} \int \mathrm{y}, \mathrm{tu}-\mathrm{t} \int \mathrm{u}, \\
\left.\text { te-tse, to-t } \int \mathrm{s}, \mathrm{ta}-\mathrm{t} \int \mathrm{a}\right]\end{array}$ \\
\hline$/ \mathrm{di}, \mathrm{dj}, \mathrm{dy}, \mathrm{du}, \mathrm{de}, \mathrm{da} /$ & $\begin{array}{l}\text { [di-d3i, dj-d3j, dy-d3y, } \\
\text { du-d34, de-d3e, da-d3a] }\end{array}$ \\
\hline $\begin{array}{l}\text { /i, } y, e, u, a, o / \text { in } \\
\text { word final position }\end{array}$ & 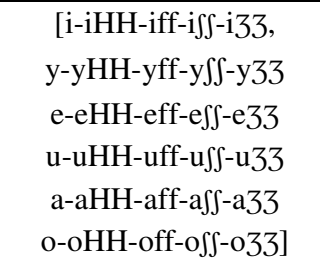 \\
\hline
\end{tabular}

This method gave the alignment system the possibility of choosing the 'standard' pronunciation or one of the variants which was our target. Whenever the system detected a fricative noise after the dental stop, or a breathy/fricative noise after the vowel or at the place of the vowel, it chose to align the signal with the non-standard variant. Some unexpected variants (affrication before /a,e,o/ and fricative coda after /a,o/) were introduced to validate the relevance of our findings. A similar method was already employed in order to identify foreign or regional accent indicators in French with the support of the alignment system [20,21] but to the best of our knowledge it was never used for social accent markers or indicators.

\section{Results}

\subsection{Consonant cluster reduction}

More than $5 \mathrm{k}$ occurrences were listened to and spectrograms looked at, and only 63 from these clusters were reducedby a deletion of $/ \mathrm{k} /$ in journalists' speech, as detailed in Table 2.

Table 2: Reduction of $/ \mathrm{ks} /$ before consonant in journalist speech. 


\begin{tabular}{|c|c|c|c|}
\hline $\begin{array}{c}\text { Type of } \\
\text { contexts }\end{array}$ & $\begin{array}{c}\text { Phonemic occ. } \\
1998-2003 \\
\text { (reduced in } \\
\text { brackets) }\end{array}$ & $\begin{array}{c}\text { Phonemic } \\
\text { occ. 2007 } \\
\text { (reduced in } \\
\text { brackets) }\end{array}$ & $\begin{array}{c}\text { Total } \\
\text { reduced } \\
\text { occ. }\end{array}$ \\
\hline$/$ kssp/ & $1064(5)$ & $2015(35)$ & $40[\varepsilon s p]$ \\
\hline$/ \varepsilon k s t /$ & $442(5)$ & $695(9)$ & $14[\varepsilon s t]$ \\
\hline$/ \varepsilon k s k /$ & $291(3)$ & $611(6)$ & $9[\varepsilon s k]$ \\
\hline All & $\mathbf{1 7 9 7}(\mathbf{1 3 )}$ & $\mathbf{3 2 4 1}(\mathbf{5 0})$ & $\mathbf{6 3}$ \\
\hline
\end{tabular}

Reduced pronunciations in journalist speech $^{1}$ globally represent just above $1 \%$, but a half of these are due to 'expliquer, explications (to explain, explanation)'. Almost the same percentage of all occurrences was produced by invited speakers in interviews. In a small number of cases (about 1\%) the speech rate was too high to decide if the cluster was reduced or highly compressed. After analysis of the data, it is possible to state that reduction of the investigated consonant clusters still remains very marginal in journalists' pronunciations although reductions tend to increase for the various forms of the root [eksplik] (i.e. the verb expliquer (explain) and other words derived from) .

\subsection{Affrication of $/ t /$ and $/ d /$}

Almost $100 \mathrm{k}$ contexts containing phonemic $/ \mathrm{t} /$ and $50 \mathrm{k}$ containing phonemic /d/ before unrounded /i,j/ were aligned, in our data from 1998 to 2010 . Figure 1 presents percentages of $/ \mathrm{t}, \mathrm{d} /$ aligned by the system with variants $/ \mathrm{t} \int \mathrm{d} 3 /$ in each context, split by period.

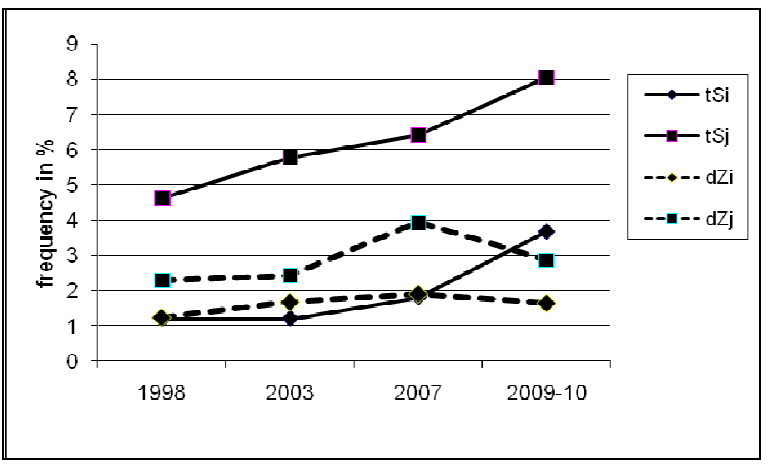

Figure 1: Evolution of /t,d/ aligned with [t],d3] variants before $/ i, j /$ in broadcast news

Such a huge number of segments could not be inspected manually, but this method to detect affrication was validated by allowing similar variants in contexts where affrication is not expected, that is $/ \mathrm{t} \int, \mathrm{d} 3 /$ preceding /a,e,o/. There were indeed $0.4 \%$ automatic alignments with variants before /e/ and there were no alignments with affricated variants before /a,o/.

The most frequent variant in these data ${ }^{2}$ is affricated $/ \mathrm{t} /$ before semi-vowel /j/. Our results show a progression of the [t $\mathrm{f}]$ variant, mostly before /j/ such in 'moitié (half), chrétien (christian)' but also before /i/ such in 'politique (policy), exécutif (executive)' especially during the last period. There is no progression for [d3] variant before $/ \mathrm{i} /$, as in 'vendredi

\footnotetext{
${ }^{1}$ The uploaded associated sample : candea_cons_reduction.wav

2 The uploaded associated sample: candea_affrication.wav.
}

(friday)' and the tendency is not clear before $/ \mathrm{j} /$, in words such 'médias (media), dialoguer (to converse)'.

Another set of almost 20k contexts containing phonemic $/ \mathrm{t} /$ and $45 \mathrm{k}$ containing phonemic $/ \mathrm{d} /$ preceding rounded $/ \mathrm{y}, \mathrm{y} /$ were also investigated. Figure 2 presents percentages of $/ \mathrm{t}, \mathrm{d} /$ alignments with variants $/ \mathrm{t} \int \mathrm{d} 3 /$ in each context, split by period from 1998 to 2010 .

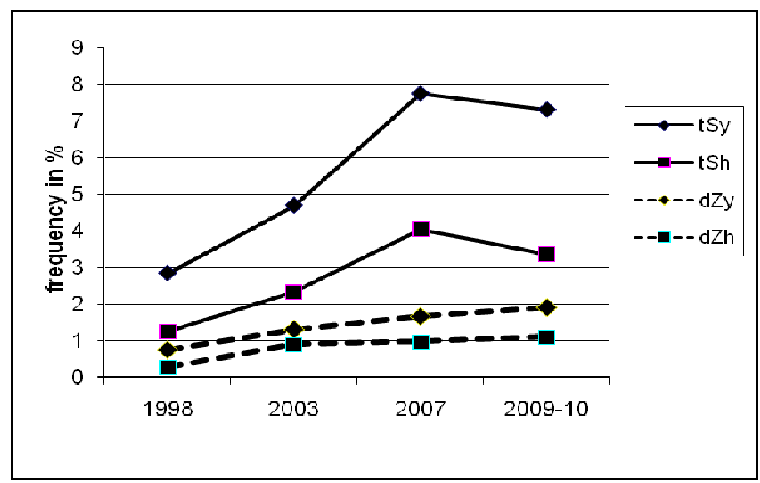

Figure 2: Evolution of /t,d/ aligned with [t],d3] variants before $/ y, y /$ in broadcast news

Results show a clear progression of [t]], such in 'actuellement (at the present time), culture' over the last period and almost no [d3] variant, both before /y, $/$.

Similar automatic alignments applied to 33 hours of Canadian broadcast news recorded in 2007 showed percentages between 16 and $19 \%$ of [tf,d3] before $/ y, y /$, which represent another way to validate our automatic method, even if affricated sounds are somewhat different in this variety of French.

\subsection{Fricative epithesis}

The alignment system generated a large number of possible hits, may of which were false alarms because our proposed variants also tend to match plenty of mouth noises, breath or background noises. The first author listened to and manually checked a set of $4 \mathrm{k}$ samples. Finally 652 examples of fricative epithesis from 1998 to 2007 were selected, which represents a very large corpus of natural non elicited speech for this unpredictable phenomenon. Since the collection is not exhaustive, it is impossible to compare by period the global frequency of this phenomenon, but it is possible to compare characteristics of samples from 1998-2003 and those from 2007, since they were extracted following the same method. All the examples were manually segmented into vocalic part and unvoiced fricative coda, or labeled as totally devoiced when it was impossible to detect a vocalic part.

Table 3. Distribution of vowels with fricative epithesis

\begin{tabular}{|c|c|c|}
\hline $\begin{array}{c}\text { Vowels followed } \\
\text { by fricative coda }\end{array}$ & $\begin{array}{c}\text { Total occ. of } \\
\text { fricative coda }\end{array}$ & $\begin{array}{c}\text { Totally devoiced } \\
\text { vowels (in \%) }\end{array}$ \\
\hline$/ \mathrm{i} /, 1998-2003$ & 154 & 39.6 \\
\hline$/ \mathrm{e} /, 1998-2003$ & 38 & 23.7 \\
\hline$/ \mathrm{y} /, 1998-2003$ & 32 & 9.38 \\
\hline \hline$/ \mathrm{i} /, 2007$ & 249 & $\mathbf{1 8 . 4 7}$ \\
\hline$/ \mathrm{e} /, 2007$ & 138 & $\mathbf{1 0 . 1 4}$ \\
\hline$/ \mathrm{y} /, 2007$ & 41 & 12.2 \\
\hline \hline All & $\mathbf{6 5 2}$ & \\
\hline
\end{tabular}


Table 3 shows an evolution of totally devoiced segments when the final vowel is /e,i/: these rate of devoiced segments halved from 1998 to 2007 . Globally, the vocalic part is wellpreserved in a large majority of our examples.

In those examples where vowels are not devoiced ${ }^{3}$, both vocalic and fricative parts were measured. Scripts for Praat software [22] were used to compute durations [23]. Figure 3, split by period, shows on one side a global stability of the vocalic duration, which corresponds to normal mean durations of vowels, and on the other side a significant progression of the duration of fricative codas (Mann-Whitney $U$ test, $p$ values are 0.0006 for $/ \mathrm{i} /, 0.003$ for $/ \mathrm{e} /$ and 0.002 for $/ \mathrm{y} /$ ). The increase in duration of the fricative coda could explain the impression of a growing phenomenon, since a longer coda tends to be more salient.

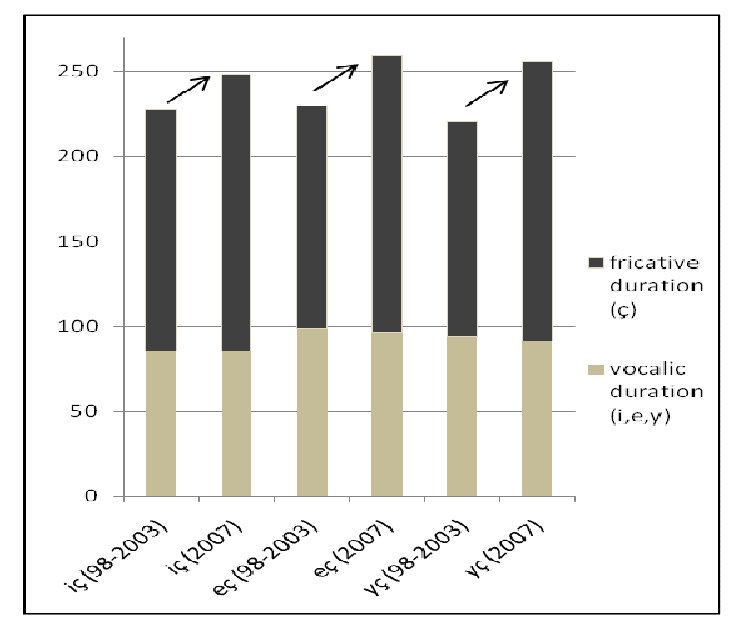

Figure 3: Duration of vocalic portions and fricative codas of the vowels /i,e,y/ (in ms)

About $41 \%$ of the 652 examples were produced by women (from $32 \%$ to $55 \%$, across vowels and periods of time), while female speakers only produced about $33 \%$ of the broadcast data. The hypothesis of a clear predominance of women in the production of this stylistic marker could not be validated. Our data seem to show that some speakers, men or women, produce a high rate of fricative epithesis while some others produce none, as argued by [15]. However, the question of a possible feminine or masculine connotation remains open.

\section{Discussion}

Despite its antiquity and its written frequency in informal French, the reduction of triple or quadruple consonantic clusters as $k s C(C)$ pronounced $s C(C)$ was found to be almost absent in journalists' speech and that supports the hypothesis of such consonantal reduction as a less educated class indicator or colloquial marker. The lack of affrication of $/ \mathrm{d} /$ in the data base also confirms the hypothesis of a '(sub)urban working class' indicator, rather unacceptable for French journalists, while this variant is common in Canadian French. In contrast, the tendency of the $/ t /$ affrication before $/ \mathrm{i}, \mathrm{j}, \mathrm{y}, \mathrm{y} /$ is seen to increase in the journalists' speech, which is compatible with both hypotheses of a possible ongoing sound change and destandardization.

\footnotetext{
${ }^{3}$ The uploaded associated sample: candea_epithesis.wav.
}

Finally, the quite recent phenomenon of fricative epithesis after /i,e,y/mostly produced in utterance final position (end of a read paragraph or before giving the floor), compatible with the destandardization hypothesis, seems to be evolving quite rapidly and requires further investigations. Without implementation of a specific acoustic model for this extraphonological French sound, our method was not able to select all examples from our data. As mentioned earlier, the method needs to be modified in order to reduce automatically the overgeneration of matches. In a large majority of our manually validated samples the vowel is not devoiced and the fricative coda is much longer than vowel. Our results support the proposal of abandoning former denomination of 'devoiced vowels' and calling it rather 'voiceless consonantal epithesis', as [11] suggested, or 'final post-vocalic fricative coda'. The behavior of this marker should be investigated in parallel with the "prepausal 2 " described by [24,25] which is a quite symmetrical vocalic epithesis, also described as rather feminine and affected.

Our findings are based on a large corpus and therefore can contribute to debates about 'supralocal' widely shared norms in French. However more qualitative investigations are necessary since inter-individual variation is very great and this is not taken into account in our data.

\section{Summary}

Studying journalists' pronunciations reveals a wealth of information about normative language practices at a given time in a society. Comparing prononciations over different times is an interesting way to challenge global hypotheses about general tendencies of social and stylistic variation in contemporaneous European French, as shown by [26] about journalists' prosody over six decades. Even if a decade could be considered as a very short period of time for a sound change, our data showed that it is possible to construct hypothesis about global tendencies from a fairly large corpus.

Semi-automatical investigations of a large broadcast news data base, with previously aligned text/speech, provided evidence against the hypothesis of progressive destandardisation in French [1] following two criteria, i.e. affrication of $/ \mathrm{d} /$ and reduction of complex consonantal clusters. Results concerning two other criteria, i.e. affrication of $/ t /$ and addition of fricative epithesis, are compatible with both the hypothesis of better acceptance of 'non-standard' phonetic features in very formal contexts (destandardization) and the hypothesis of ongoing phonetic changes. Further investigations resulting from cross-fertilization between corpus linguistics and qualitative research in sociophonetics may lead to a better description of ongoing language changes. Such descriptions require to combine situated studies about social meaning of particular variants and pattern-driven studies [27] about the community pattern of use.

\section{Acknowledgements}

This work was partly realized under the Quaero Programme www.quaero.org, funded by OSEO, French State agency for innovation, during a stay of the first author as visiting scholar to the LIMSI laboratory. It was also supported by the Labex «Empirical Foundations of Linguistics» (ANR/CGI) Program, from Sorbonne Paris Cité. 


\section{References}

[1] Armstrong N., Pooley T., Social and linguistic Change in European French, Palgrave Macmillan, 2010.

[2] Gauvain J.-L. \& al., "Where are we in transcribing French broadcast news?", Interspeech, Lisbon, 2005.

[3] Lamel L. \& al., "Speech recognition for machine translation in Quaero", in IWSLT, San Francisco, 2011.

[4] Lyche C. "Le français de référence: éléments de synthèse", in Detey S. \& al., Les variétés du français parlé dans l'espace francophone: ressources pour l'enseignement, Ophrys, Paris, 143-165, 2010.

[5] Castellotti V. \& Robillard D. (de), "Des Français devant la variation: quelques hypothèses", in Cahiers de l'Institut Linguistique de Louvain 29:223-240, Peeters, 2003.

[6] Fonagy, I. 'Le français change de visage?', Revue romane, 24:2, 225-253, 1989.

[7] Fonagy, I. Dynamique et changement, Peeters, 2006.

[8] Lodge R. A., A sociolinguistic history of Parisian French, Cambridge, 2004.

[9] Adda-Decker and al., "Investigating syllabic structures and their variation in spontaneous French", in Speech Communication, 46:119-139, 2005.

[10] Queneau R. Zazie dans le métro, Gallimard, Paris, 1960.

[11] Fagyal Z. Accents de banlieue. Aspects prosodiques du français populaire en contact avec les langues de l'immigration, L'Harmattan, 2010.

[12] Vernet M., Trimaille C., "Contribution à l'analyse de la palatalisation en français parlé contemporain", in Hornsby D., Jamin M. (Eds.) Nottingham French Studies 46, 2:82-99, 2007.

[13] Trimaille, C. "Who's not palatalizing? Trying to understand the status of palatalized variants in French", 8th Conference of the HDLS, Albuquerque, New Mexico, 6-8 November 2008.

[14] Trimaille C., Candea M., Lehka-Lemarchand I., "Existet-il une signification sociale stable et univoque de la palatalisation/affrication en français? Étude sur la perception de variantes non-standard", in Actes $d u$ $C M L F$, http://www.linguistiquefrancaise.org/index.php, 2012.

[15] Candea M. "Au journal de RFI-chhh et dans d'autres émissions radiodiffusée-chhhs. Les épithèses consonantiques fricatives", in Le discours et la langue, Louvain, 3:136-149, 2012.

[16] Mettas O., La prononciation parisienne. Aspects phoniques d'un sociolecte parisien (du Faubourg StGermain à la Muette), Paris, SELAF, 1979.

[17] Paternostro R., "Le dévoisement des voyelles finales, étude perceptive" in Rassegna italiana di Linguistica applicata, 3:40,129-158, 2008

[18] Fagyal, Z., Moisset, Ch., "Sound change and articulatory release: where and why are high vowels devoiced in Parisian French ?", in Proc. of ICPhS , San Francisco: 309-312, 1999.

[19] G. Gravier et al., "The ESTER evaluation campaign of rich transcription of French broadcast news", in Proc. of LREC, Lisboa, 885-888, 2004.

[20] P. Boula de Mareüil, B. Vieru-Dimulescu, C. Woehrling, M. Adda-Decker, "Accents étrangers et régionaux en français. Caractérisation et identification", in Traitement Automatique des Langues 49(3): 135-162, 2008.
[21] Vieru-Dimulescu B., Boula de Mareuiil P., Adda-Decker M., "Characterizing non-native French accents using automatic alignement", 16th ICPhS, Sarrebruck, 22172220, 2007.

[22] Boersma, Paul \& Weenink, David (2013). Praat: doing phonetics by computer [Computer program] from http://www.praat.org.

[23] Gendrot C., http://ed268.univ-paris3.fr/lpp/pages/ EQUIPE/gendrot/page_web/scripts.htm

[24] Hansen A.B. \& Hansen M.M., "Le [ə] prépausal et l'interaction", in Etudes Romanes, 54:89- 109, 2003.

[25] Carton, F., "L'épithèse vocalique et son développement en français parlé " in Faits de langues, Paris, 13: 35-45, 1999.

[26] P. Boula de Mareüil, A. Rilliard \& A. Allauzen, "A diachronic study of initial stress and other prosodic features in the French news announcer style: corpusbased measurements and perceptual experiments", in Language and Speech 55(2): 263-293, 2011.

[27] Di Paolo M., Yaeger-Dror M., Sociophonetics: A Student's Guide, Routledge, 2010. 